\title{
Transmission Mechanisms through Which Institutions Mediate the Process of Globalization to Influence Poverty Levels
}

\author{
Kossi Ayenagbo \\ Department of Economy, University of Kara, Kara, Togo \\ Email: ayenagbo@yahoo.fr
}

How to cite this paper: Ayenagbo, K. (2021). Transmission Mechanisms through Which Institutions Mediate the Process of Globalization to Influence Poverty Levels. Modern Economy, 12, 787-803.

https://doi.org/10.4236/me.2021.124039

Received: March 8, 2021

Accepted: April 20, 2021

Published: April 23, 2021

Copyright $\odot 2021$ by author(s) and Scientific Research Publishing Inc. This work is licensed under the Creative Commons Attribution International License (CC BY 4.0).

http://creativecommons.org/licenses/by/4.0/

\begin{abstract}
The Sub-Saharan region (SSR) has a rapid population growth, challenges of food security and political adjustments which have been making efforts to cope with global partner expectations. This study analyses the development and status of institutions which have been established in the SSA to affect the demands of globalization and poverty reduction for the countries of Sub-Saharan Africa over the period 2010-2018 using a panel data set. The GMM model used in this study estimated that trade liberalization has increased poverty in the SSR. The results analysis showed that the effect of increasing trade liberalization on poverty decreases with the quality of institutions. The coefficient linked to the interactive variable was found to be negative and significant at the $10 \%$ threshold, showing that when the quality of governance is good, the effect of increasing the openness rate on poverty decreases by $0.2146 \%$. The estimation of the simultaneous equation model by SUR method also revealed that the quality of institutions, particularly the index of regulation of business activities, was positively affecting trade liberalization, which in turn led to poverty reduction.
\end{abstract}

\section{Keywords}

Sub-Saharan Africa, Institutions, Globalization, Poverty, GMM

\section{Introduction}

Globalization is a broad concept used to describe a variety of phenomena that reflect increased economic, social and political interdependence of countries (Samimi, Lim, \& Buang, 2011). However, poverty reduction remains at the heart of the post-2015 development agenda. The determinants of poverty reduction remain debated in literature, in particular the role of structural conditions linked 
to the quality of institutions. It is estimated that about 783 million people live below $\$ 1.90$ a day worldwide. This was one of the reasons that prompted the United Nations to set the first sustainable development goal (SDG) aimed at the "eradication of extreme poverty from people everywhere" by 2030 (Kenny, 2015). Globally, the overwhelming majority of people living below the poverty line are found in the South Asia and in the sub-Saharan Africa (SSA). Among the regions of the world most affected by poverty, sub-Saharan Africa has 50 million more poor people today than 40 years ago, with 403.2 million people living in poverty. About 165 million poor people lived in Latin America and the Caribbean (Schoch \& Lakner, 2020).

In such a context, the fight against extreme poverty in this region requires the establishment of practical-oriented solutions anchored on adequate economic policies at national and international level. As such most countries in the SSA region have adopted and are implementing the liberalization of economies through free trade, the mobility factors of production and technology transfer with the anticipated hope of spurring economic growth and thereby attaining poverty reduction. However, this economic globalization has come with it many challenges for many African countries, especially in the sub-Saharan region. According to the World Bank (2016), forty-eight percent (48\%) of the population in sub-Saharan Africa live on less than a dollar a day while forty percent (40\%) of South Asia live on less than a dollar a day. Accordingly, the neo-liberal conception (Chenery, 1974; Peemans, 1996; Bhalla \& Lapeyre, 1999), has accused globalization of excluding the poorest from the fruits of the growth it generates or, in any case, of making them benefit proportionately less. In the 21st century, Africa has emerged as one of the most populous continents and one of the most richly endowed regions with natural resources. At the same time, the majority of the population does not access the benefits of global free trade but, on the contrary, suffers the harmful effects of global warming in climate change, causing situations of famine, civil war and migratory crisis (Assens, 2019).

The relationship between globalization and poverty reduction has been widely documented. For some, globalization generally helps to reduce poverty (Collier \& Dollar, 2002). However, this effect is not the same for the different forms of globalization. Economic and social globalizations contribute significantly to reducing poverty in the world while political globalization does not contribute to poverty reduction (Farzana, 2018). Studies in sub-Saharan African countries have shown that globalization has made richer countries and peoples richer while poor countries and populations remain poorer unlike the win-win situation envisioned by globalization for all the nations and all the peoples of the world (Uzonwanne, 2018).

The works cited above suggest a relationship between globalization and poverty reduction. Nevertheless, others strongly believe that the process of poverty reduction is influenced by the quality of governance institutions in a country. However, results or evidences on the ground remain mixed (Dalgaard \& Erickson, 2009; Fiszbein, Kanbur, \& Yemtsov, 2014; Kwon \& Kim, 2014; Smith \& 
Haddad, 2015; Sumner \& Tiwari, 2009).

Over the past two decades, poverty has considerably been reduced, even in countries like Uganda and Bangladesh, which rank poorly on a wide range of governance quality indicators. This has called into question that cannot be ultimate "governance trap" standards (Asadullah, Savoia, \& Wahiduddin, 2014; Mahmud, Asadullah, \& Savoia, 2013; McGee, 2000). At the same time, the global adoption of the MDGs in itself, had an element of global governance, and most likely mobilized political consensus around the poverty reduction agenda and served as a focal point for political advocacy (Fukuda-Parr, 2011; Fukuda-Parr \& Hulme, 2011; Hulme et al., 2015; Waage et al. 2010).

Most of the work towards poverty reduction lacked precision on the role that the quality of institutions can play in the process of globalization and poverty reduction. In sub-Saharan Africa, where the governance problem arises, very little attention is paid on how the quality of institutions could act as a complement or substitute for globalization to reduce poverty (Asamoah et al., 2016). This paper examined the interplay of economic institutions in the process of globalization and efforts aimed at poverty reduction in sub-Saharan Africa.

The rest of the paper is organized as follows: Section 1 presents the different channels through which globalization affects poverty, Section 2 discusses the methodology, and Section 3 presents the results followed by discussions. Section 4 presents the conclusion of the research and policy implications.

\section{Article Perspective}

\subsection{Channels through Which Globalization Influences Poverty}

Globalization is conceptualized as "a process that erodes national boundaries, integrates national economies, cultures, technologies and governance, and produces complex relationships of mutual interdependence (Dreher, 2006)". There are different channels through which globalization influences poverty and in the process produces winners and losers (Culpeper, 2005; Nissanke \& Thorbecke, 2006; Harrison \& McMillan, 2007; Goff \& Singh, 2014).

The first channel through which globalization affects poverty is the relative price of inputs and outputs (Nissanke \& Thorbecke, 2008).

\subsection{The Heckscher-Ohlin Model and the Stolper-Samuelson (SS) Theorem}

In the literature, the effects of globalization on the poor are generally described through the implications of the Heckscher-Ohlin (HO) model. According to this model, in an open economy, a country where unskilled labor is abundant will specialize in the production of goods that require unskilled or low-skilled labor. Developing countries have an abundant unskilled labor force. Therefore, developing economies will produce goods that require intensive use of unskilled or low-skilled labor. The growing demand for unskilled labor will lead to increase in the wages of the poor, which will initially see a reduction in inequalities and 
poverty (Autor et al., 1998).

The implications of the $\mathrm{HO}$ model are based on the assumption of identical technologies from one country to another. However, trade openness can also results in technology transfer to the developing world. As technology is inherently skill-biased, the diffusion of technology in the developing world increases the demand for highly skilled workers. This trend triggers a growing demand for highly skilled workers which cause an increase in wages and in turn worsen income distribution. The ultimate result can be the marginalization of the poor.

Davis and Mishra (2007) also argued that the HO model implicates that trade liberalization increases the wages of unskilled labor is "worse than bad". They claim that this implication is based on an inadequate understanding of the Stolper-Samuelson (SS) theorem. Furthermore, the Stolper-Samuelson theorem was postulated to be valid under the following conditions: 1) if all trading countries produce all goods; 2) Goods produced in one country are close substitutes for goods produced abroad; 3) The comparative advantage can be fixed for all trading partners.

Indeed, trade openness can lead to an increase in unemployment and poverty. This is because labor market distortions (i.e. imperfect labor mobility or minimum wage legislation) limit the favorable outcomes of trade openness for the poor. Furthermore, empirical evidence from developing economies such as Poland and India also suggest that the workforce is not as mobile as the $\mathrm{HO}$ model considers it to be (Harrison \& McMillan, 2007). In real life, there are different barriers to labor mobility. In addition, poor people in developing economies may not benefit from trade because they typically work in sectors that are historically protected, such as textiles and clothing. Therefore, trade reforms may result in less protection for unskilled workers, leaving them very vulnerable and slipping into deeper poverty.

The Heckscher-Ohlin-Samuelson-Stolper (HOSS) model assumes that the workforce is perfectly mobile within the country and immobile from one country to another. However, this assumption is unrealistic as there are different barriers to labor mobility (Goff \& Singh, 2014). Likewise, cross-border movements have always been an important factor in the process of globalization, but the differences in ease of mobility cross-border workforce is another important channel through which globalization produces winners and losers in today's world.

It should be noted that the convergence of incomes in the globalizing countries (Atlantic countries) during the first wave of globalization is attributed to labor migration (1870-1914). Williamson (2005) noted that around six million people, including skilled and unskilled labor, left Europe for the New World during this period. In contrast, labor mobility in the current period of globalization differs considerably between unskilled and skilled labor (World Bank, 2002). Therefore, the "equalization of wages" theorem given by HOSS is perhaps less likely to materialize in labor migration in the current phase of globalization (Nissanke \& Thorbecke, 2008).

In addition, the theory predicts that high-yielding capital should flow to de- 
veloping economies with high marginal productivity of capital (MPK). If these are countries with higher rates of technical change, such an occurrence may inflate the wage rate in the developing countries. However, capital does not move to finance development projects in developing economies as the theory predicts (Lucas Paradox).

\subsection{Status of the Distribution of Foreign Assets in Developing Countries}

Obstfeld and Taylor (2001) observed that the current distribution of foreign assets is essentially an exchange of assets by rich countries and that it is much more a question of sharing and hedging of risks than of financing in long term. Culpeper (2005) concluded that the unique aspects of factor movement in the current wave of globalization are 1) Labor and capital migrate more between developed countries than between developing countries; 2) Skilled labor from developing countries tends to migrate to developed countries; 3) Capital flows also tend to shift to developed countries, especially in times of uncertainty or crisis. With such "ubiquitous" movements, Culpeper (2005) asserted that developed countries will experience a decrease in inequality while developing economies will suffer from increasing inequality. In the end, this will lead to increased poverty in developing countries due to increasing globalization.

\subsection{Effects of Globalization on Technological Progress and Diffusion of Technology}

Technological advancement or the diffusion of technology is another channel through which globalization affects poverty. Technological changes emanate from industrialized countries because of the resource endowments of these countries. Furthermore, technological change is inherently skill-biased and tends to increase inequalities in developed and developing countries alike (Culpeper, 2005). However, it is semi-skilled or skilled labor that benefits from technological change, while unskilled labor is marginalized and deteriorates in response to technological change (Goff \& Singh, 2014).

Kanbur (1998) considers technological change as one of the potential sources of the widening gaps between unskilled and skilled labor. Likewise, Agenor (2004) also noted that greater trade openness and economic integration leads to a significant substitution between unskilled labor and capital, unlike greater complementarity between skilled labor and capital.

Furthermore, access to technology and differences in technology are not spontaneous. Therefore, the productivity differential can increase over time and can increase income inequality between countries. In this regard, Easterly (2004) added that the productivity differential between countries has been a determinant of trade and income inequality. Indeed, technological dissimilarities between countries that innovate and emulate are still important factors in explaining income and wage inequality at the global level (Vernon's (1979) product cycle model). 


\subsection{The Divers Degrees in Privatization of Agriculture}

In addition, globalization has intensified the process of privatization of research. This trend has been stronger in the agricultural sector than elsewhere (Pray et al., 2003). In addition, the green revolution led by the public sector has been replaced by a biotechnology revolution led by the private sector. An important question now is whether or not poor farmers can adopt biotechnology and, if not, what are the possible consequences in terms of distribution and poverty. It is argued that poor farmers in developing economies cannot afford to buy genetically modified (GM) seeds as they are mainly engaged in subsistence agriculture (Nissanke \& Thorbecke, 2008). Our local farmer interviews also strongly suggested that it is also now evident that the transgenic hybrid seeds have a higher demand for fertilizers and pesticides compared to indigenous seeds.

\subsection{Volatility and Shock Vulnerability in Developing Countries}

It is important to mention that globalization is also linked to greater uncertainty. There is a possibility of extreme fluctuations in output, income and employment which are caused by global shocks. For example, the high volatility of consumption in Central and Eastern Europe during the 1990s was linked to trade shocks which resulted from trade liberalization (Nissanke \& Thorbecke, 2008).

Culpeper (2005) argued that poor families suffer disproportionately more during periods of contraction than they gained during periods of expansion. In this regard, Birdsall (2002) had earlier provided evidence to validate the theoretical proposition that poor households are less able to protect themselves against negative shocks. The Asian financial crises also showed that poor households suffered disproportionately during the downturn in economies (Nissanke \& Thorbecke, 2006). This analysis indicates that greater openness is linked to economic shocks and that the poor may be more vulnerable to these shocks.

\subsection{The Influence of Global Integration on Information Flow and Poverty}

Another channel through which globalization has affected poverty and inequality is in knowledge and the flow of information. The cost of transmitting information is practically negligible in the current phase of globalization and, as a result, the flow of information has increased (Majeed \& Khan, 2019). Consequently, internet technology and the media have been extrapolated to have great potential in improving the technical and human capital of individuals in developing economies. The flow of information has enormous potential to accelerate the development process. Graham (2004) nevertheless argued that increasing the flow of information about the quality of life of others can affect benchmarks. Such information can increase dissatisfaction among certain income groups in poor countries, and people in a particular income groups may tend to compare their standard of living with that of similar income groups in developed countries. Thus, greater openness may also increase the insecurity as well as the vul- 
nerability of many cohorts, especially those who lack the capacity to benefit from global integration (Nissanke \& Thorbecke, 2006). In addition, due to the uneven distribution of information, the poor are often left poor and are not able to benefit from globalization.

\subsection{Global Disinflation}

Rogoff (2003) pointed out that improved fiscal policy, the effective role of central banks, deregulation and increased globalization help reduce inflation globally. Nonetheless, global disinflation is the result of higher levels of competition in the labor and goods markets. While lower inflation levels benefit the poor, this macroeconomic stability and lower inflation levels should not come at the expense of economic growth, otherwise they can hurt the poor at the same time.

\subsection{The Influence of Quality of the Institutions on the Globalization Agenda}

Institutions mediate the various transmission mechanisms through which globalization affects poverty (Sindzingre, 2005). Institutions help to understand the diverse, heterogeneous and non-linear outcomes of global integration. In addition, institutions serve as filters, which intensify or hinder the transmission between globalization and poverty. These filters work at the global level, at the country level and even at the city level. It is important to mention that international organizations such as the WTO and the IMF often create their own rules of the game and these rules determine poverty outcomes. Likewise, institutions in developed countries protect their agricultural sector from exports from developing countries, thereby depriving the poor in developing countries of the benefits of openness. This is largely true for countries in sub-Saharan Africa (Nissanke \& Thorbecke, 2008).

Likewise, globalization can also revolutionize the institutional environment. As globalization advances, new norms and conventions of interaction are likely to emerge. Likewise, new standards for transparency, contracts, governance, law and human rights are being developed. Nonetheless, institutional changes are slow and operate on the margins, due to the informal constraints of societies (North, 1990).

\subsection{The Role of Institutions in Globalization Process}

Institutions have an important role to play in harnessing the benefits of globalization. For example, the negative effects can be countered by putting in place safety nets. In this regard, Sindzingre (2005) suggested that globalization could exclude many people when it is mediated by social polarization, oligopolistic structures, and past regimes that can prevent a particular group of poor people from enjoying the benefits of globalization. Whereas the favorable effects of globalization for the poor materialize when the institutional conditions are developed through elements such as social cohesion, wider political participation and better management of social conflicts resulting from globalization. There- 
fore, maximum gains can be achieved through the presence of strong and well-functioning institutions (Goff \& Singh, 2014).

Some authors also argued that liberalization of the trade and investment sectors can only lead to economic growth and poverty reduction if certain institutional preconditions, including private property protection and the rule of law are in place. Property rights, contract enforcement and corruption have an impact on the type and stability of trade, capital and investment that enter countries (Collier \& Gunning, 1999; Collier \& Dollar, 2002). For example, Klein \& Olivei (2008) found that the economic and regulatory institutions associated with financial deepening were necessary for developing countries to benefit from liberalization. At the same time, others foresaw that trade liberalization actually improved institutions (Dollar \& Kraay 2003), but later researches showed that this is not necessarily the case (Rodrik, 2007; Do \& Levchenko, 2009). Beyond the welfare losses at the national level due to the decline in trade, the poor are less able to benefit without having access to credit.

This lack of credit prevented them from increasing investment in their land, skills, crops or businesses and from taking advantage of the changing economic opportunities of globalization (McCulloch et al., 2001; Collier \& Dollar, 2002).

Because labor mobility is a key assumption that supports HOS's forecast, the inflexibility of labor laws during liberalization is another example of an institution that can derail gains for the poor. Many developing countries have rigid labor market policies that have been slow to change as a result of globalization (Rudra \& Tobin, 2017). If rural and urban labor cannot be easily reallocated within and between sectors in response to price changes induced by liberalization, export sectors develop less efficiently and the poor lose access to new and better income opportunities (Goldberg \& Pavcnik, 2004).

This literature analysis shows the role that institutions could play in the process of globalization and poverty reduction. However, from an empirical point of view, the work carried out in sub-Saharan Africa lacks precision on the role that the quality of institutions would play in this process and created an information gap that must be empirically filled.

\section{Methodology}

The dependent variable is the poverty rate, measured by the number of people living on less than $\$ 1.9$ per day as defined by the World Bank. We collected data from the World Development Indicators (WDI) from 2010 to 2018 of sixteen (16) countries in sub-Saharan Africa for which this kind of data are available.

The explanatory variables of interest in the context of this study are an indicator of globalization and the index of institutional governance. Globalization is a multidimensional concept with three basic dimensions: economic, social and political. We were particularly interested in economic globalization. Economic globalization is measured by several indicators. FDI refers to total foreign direct investment as a percentage of GDP. These are the net inflows of investments intended to maintain the management control of a company operating in a foreign 
country. Several empirical studies associated FDI with greater inequality (Aitken et al., 1996; Feenstra \& Hanson, 1997; Herzer et al., 2014). Ridzuan et al. (2017) examine the effect of FDI inflows and FDI stock on income distribution for seven Southeast Asian countries from 1990 to 2013 and found that larger FDI inflows exacerbate income inequality.

Remittances include personal transfers and compensation of employees, in cash or in kind. In countries of Latin America and the Caribbean, remittances appear to stimulate growth and reduce inequalities (Acosta et al., 2007). A 2006 household survey in Mali (Gubert et al., 2010) indicates that remittances reduce income inequalities by around 5\%. Other studies, however, reveal that the migration and remittances increase inequalities in Ghana (Taylor et al., 2005), in rural areas of Egypt (Adams, 1991) and in sub-Saharan and northern Africa (Anyanwu, 2011).

Hérault (2007) analyzed the effects of trade liberalization on poverty and inequality in South Africa using a macro-oriented CGE model and a micro simulation (MS) model. The study revealed that trade liberalization results in poverty reduction for white South Africans, who are the main beneficiaries of this policy. Ametoglo et al. (2018) argues that if regionalism can reduce poverty in Africa, it would require a shift from trade reform-oriented integration to transformative regionalism, that is, an integration approach that promotes and ensures progress in building productive capacities and achieving structural transformations for sustainable development. Kweka and Mboya (2004), in a case study from Tanzania, found that regional integration within SADC and EAC improved trade. They also noted that regional trade has a greater impact on poverty reduction as it directly provides jobs and sales opportunities for the poor in context.

We hereby present the National Policy and Institutional Assessment Index (CPIA) as a corruption variable. The CPIA exemplifies transparency, accountability and corruption in the public sector. Tebaldi and Mohan (2010) observe that an economy with strong corruption control, supported by effective governance structures or institution, produces favorable conditions to promote growth and alleviate conflicts in income distribution. In addition, there is a large body of literature that demonstrates that corruption worsens income inequalities (Chetwynd et al., 2003; Gyimah-Brempong, 2002).

\subsection{Models}

The poverty model inspired by the work of Dollar and Kraay (2004) is as follows:

$$
\ln \text { povi }_{i}=\alpha_{0}+\alpha_{1} \ln G I N I_{i}+\alpha_{3} \ln y_{i}+\alpha_{4} X_{i}+\varepsilon_{i}
$$

This equation represents the cross-sectional analysis of poverty where, for a country $i, i=1,2, \cdots, n$, pov measures the proportion of poor people in the country for a given year, GINI measures income inequalities, $y$ the GDP growth rate and $X$ a vector of variable likely to influence the poverty rate.

Global integration plays an important role in poverty reduction. Studies by 
Bhagwati and Srnivasan (2002) and Dollar and Kraay (2004) conclude that economic openness is likely to reduce poverty while increasing growth. Other studies find that deep integration into the global economy benefits the poor less, who are more vulnerable to its shocks (Culpeper, 2005). Taking this aspect of globalization into account, Equation (1) can be rewritten as follows:

$$
\ln \text { povi }_{i}=\alpha_{0}+\alpha_{1} \ln G I N I_{i}+\alpha_{3} \ln y_{i}+\alpha_{4} X_{i}+\alpha_{4} \ln \text { Glo }_{i}+\varepsilon_{i}
$$

where is the elasticity of poverty with respect to globalization?

It also emerges that the quality of institutions affects poverty either directly or indirectly. In this case, the quality of institutions can act as a complement or substitute for globalization. Taking into account such a relation makes it possible to rewrite Equation (2) as follows:

$$
\begin{aligned}
\ln \text { povi }_{i}= & \alpha_{0}+\alpha_{1} \ln \text { GINI }_{i}+\alpha_{3} \ln y_{i}+\alpha_{4} X_{i}+\alpha_{4} \ln \text { Glo }_{i} \\
& +\alpha_{6} \text { Gouv }_{i}+\alpha_{7} \ln \text { Glo }_{i} * \text { Gouv }_{i}+\varepsilon_{i}
\end{aligned}
$$

By applying to the panel data, we have:

$$
\begin{aligned}
\ln \text { povi }_{i t}= & \alpha_{0}+\alpha_{1} \ln G_{I N I_{i t}}+\alpha_{3} \ln y_{i t}+\alpha_{4} X_{i t}+\alpha_{4} \ln \text { Glo }_{i t} \\
& +\alpha_{6} \text { Gouv }_{i t}+\alpha_{7} \ln \text { Glo }_{i t} * \text { Gouv }_{i t}+\varepsilon_{i t}
\end{aligned}
$$

\subsection{Estimation Methods}

The role of institutions in the process of globalization and poverty reduction poses two econometric problems. First, the poverty at instance $t$ can be explained by the past poverty rates. Second, the quality of institutions can have a direct and indirect effect via globalization on the poverty rate. In this context, our estimated econometrics is based on two methods. First, we estimate our model using the generalized least squares (GMM) method by delaying the dependent variable and the explained variable of interest by a period. Then, the estimation of the model with simultaneous equations by the SUR method makes it possible to analyze the direct and indirect effects of the quality of institutions on poverty.

The dynamic panel equation looks like this:

$$
\begin{aligned}
\ln \text { povi }_{i t}= & \alpha_{0}+\alpha_{1} \ln \text { pov }_{i t-1}+\alpha_{2} \ln \text { GINI }_{i t}+\alpha_{3} \ln y_{i t}+\alpha_{4} X_{i t}+\alpha_{5} \ln \text { Glo }_{i t} \\
& +\alpha_{6} \ln \text { Glo }_{i t-1}+\alpha_{7} \text { Gouv }_{i t}+\alpha_{8} \ln \text { Glo }_{i t} * \text { Gouv }_{i t}+\varepsilon_{i t}
\end{aligned}
$$

Second, the model is estimated by the SUR technique. Such a technique will make it possible to highlight globalization as the channel through which the quality of institutions affects the level of poverty.

$$
\left\{\begin{array}{l}
\ln \text { pov }_{i t}=\alpha_{0}+\alpha_{1} \ln \text { Glo }_{i t}+\alpha_{2} X_{i t}+\varepsilon_{i t} \\
\ln \text { Glo }_{i t}=\beta_{0}+\beta_{1} \text { Gouv }_{i t}+\beta_{2} Z_{i t}+\varepsilon_{i t}
\end{array}\right.
$$

where, $X, Z$ are vectors of control variables. Globalization is measured by economic liberalization (the openness rate). The quality of institutions includes: business institutions (the time required to start an income-generating activity, the index of regulation of business activities), transparency in the management 
of public goods, macroeconomic management.

\section{Results and Discussions}

\subsection{Descriptive Statistics of Variables}

The results of Table 1 show that on average, the poverty rate in the countries of sub-Saharan Africa is $41.27 \%$ with a minimum of $13.65 \%$ and a maximum of $58.7 \%$. The openness rate in most countries is below 0 . This shows that the volume of exports cannot cover the country's imports. The institutional quality indices are between 2.5 and 4.5 (Table 1 ).

\subsection{Econometrics Analysis}

The results showed that trade liberalization increases the poverty rate in sub-Saharan Africa with an elasticity of 0.68. Indeed, the literature shows that trade openness can lead to an increase in unemployment and poverty. Labor market distortions for example (i.e. imperfect labor mobility or minimum wage legislation) limit the favorable outcomes of trade openness for the poor (Harrison \& McMillan, 2007). In real life, there are different barriers to labor mobility. In addition, poor people in developing economies may not benefit from trade because they typically work in sectors that are historically protected, such as textiles and clothing. Therefore, trade reforms may result in less protection for unskilled workers.

The results of Table 2 also show that the effect of increasing trade liberalization on poverty decreases with the quality of institutions. The coefficient linked to the interactive variable is negative and significant at the $10 \%$ threshold, showing that when the quality of governance is good, the effect of increasing the openness rate on poverty decreases by $0.2146 \%$. This result corroborates with studies which find that institutions mediate the various transmission mechanisms through which globalization affects poverty (Sindzingre, 2005). Transparency in public management reduces poverty. At the $5 \%$ threshold, an improvement in the transparency index by one point reduces the poverty rate by $7.6181 \%$.

Finally, the model estimated by the SUR method highlights the effect of the quality of institutions on poverty through economic liberalization.

The results show that the Business Regulation Index positively affects trade openness, which in turn helps reduce poverty (Table 3 ). Other indicators of the quality of institutions such as transparency in public management, the time required to start a business directly affect the poverty rate. Thus, the quality of institutions has an important role to play in reaping the benefits of globalization. Some authors argued that liberalization of the trade and investment sectors can only lead to economic growth and poverty reduction if certain institutional preconditions, including private property and the rule of law are in place. Property rights, contract enforcement and corruption have an impact on the type and stability of trade, capital and investment that enter countries (Collier \& Gunning 1999; Collier \& Dollar, 2002). 
Table 1. Poverty rate, GDP and population growth rate.

\begin{tabular}{cccccc}
\hline Variables & Obs & Mean & Std. Dev & Min & Max \\
\hline Poverty rate & 144 & 41.2688 & 11.90259 & 13.65 & 58.7 \\
Population Growth rate & 144 & 2.784655 & 0.5028947 & 1.357697 & 3.907245 \\
GDP growth rate & 144 & 5.189256 & 3.11979 & -8.130444 & 14.04712 \\
Time required to start an activity & 144 & 22.80213 & 13.83885 & 5.5 & 84 \\
Macroeconomic management rank- & 144 & 3.725926 & 0.5589119 & 2 & 4.5 \\
$\quad$ ing index & 144 & 3.303704 & 0.5363513 & 2 & 4.5 \\
FISC political management index & 144 & 2.874074 & 0.4759849 & 2 & 2 \\
Transparency index & 144 & 3.277778 & 0.4261362 & 2.5 & 4.5 \\
Public administration quality index & 144 & -11.04427 & 21.60055 & -87.07963 & 41.68043 \\
The opening rate & & & & & \\
\hline
\end{tabular}

Source: Author, based on World Bank data.

Table 2. Econometric results using the GMM method.

\begin{tabular}{cc}
\hline Independent variables & \\
\hline Poverty rate $(-1)$ & $-0.2000^{* * *}$ \\
Opening rate & $0.6810^{* * *}$ \\
Opening rate & $0.3353^{* *}$ \\
Interactive variable & $-0.2146^{* * *}$ \\
Population growth rate & -5.9087 \\
Time required to start an activity & -0.0417 \\
Macroeconomic management ranking index & -1.2400 \\
Transparency index & $-7.6181^{* *}$ \\
Constant & $79.8111^{\star}$ \\
Number of instruments & $=49$ \\
Wald chi2 $(11)$ & $=18.26$ \\
Prob $>$ chi2 & $=0.0757$ \\
\hline
\end{tabular}

Source: Author, from Stata Software. NB: ${ }^{*}$ significance at $1 \%,{ }^{* *}$ significance at $5 \%,{ }^{* *}$ significance at $10 \%$.

Table 3. Econometric results using the SUR method.

\begin{tabular}{ccc}
\hline & Trade liberalization & Poverty Rate \\
\hline Interactive variables & & $-0.2580^{*}$ \\
Macroeconomic management index & 4.4282 & -1.7245 \\
Commercial activity regulation index & $16.0872^{*}$ & $-5.1464^{* *}$ \\
Transparency index & $-12.5561^{*}$ & 1.0217 \\
GDP Growth rate & 0.1298 & -0.1845 \\
Time required to start an activity & 0.0499 & $-0.1609^{* *}$ \\
Population growth rate & -2.0275 & -0.2626 \\
Constant & $-28.4789^{* * *}$ & $89.9811^{\star}$ \\
Number of instruments & & $=49$ \\
Wald chi2 $(11)$ & & $=18.26$ \\
Prob $>$ chi2 & & $=0.0757$ \\
\hline
\end{tabular}

Source: Author, from Stata Software. ${ }^{*}$ significance at $1 \%,{ }^{* *}$ significance at $5 \%,{ }^{* * *}$ significance at 10. 


\section{Conclusion and Recommendations}

The econometric results were obtained using two estimation methods: the GMM method and the SUR method in simultaneous equations. Globalization is measured in this study by economic liberalization. The indices of the quality of the institutions selected were: transparency, trade regulations, macroeconomic management and the time required to start a business. Empirical results firstly, reveal that the degree of openness of sub-Saharan African countries increases poverty in the sub region. However, we conclude that this effect of increasing poverty is mitigated when the quality of institutions is taken into account in the globalization process. The results also show that the quality of institutions affects poverty through globalization. The model estimation by the SUR method shows that the index of regulation of business activities positively affects the degree of trade openness, which in turn helps reduce the poverty rate.

This analysis suggests the following policy implications: Sub-Saharan African countries must gradually open up to the global market (trade liberalization, export promotion, import substitution strategy, establishment of clear objectives, market survey, choice of entry mode, consideration of financing and insurance needs, drafting if possible of a strategic document for entry into the world market ...) to limit the negative effects of globalization with regards to poverty. The quality of institutions needs strengthening and improvement through effectiveness and independence of operations, particularly in the area of trade and the fight against corruption. This is critically essential to harness the positive effects of globalization. However, this study encountered certain limitations, notably the availability of data over a longer period and for all countries of sub-Saharan Africa, the complexity of the concept of poverty in relation to its measurement indicator, the complexity of the concept of globalization and its measurement indicator in relation to its dimension and therefore the policy implications recommendation should be viewed with some regional consideration.

\section{Conflicts of Interest}

The author declares no conflicts of interest regarding the publication of this paper.

\section{References}

Acosta, P., Lopez, J. H., \& Fajnzylber, P. (2007). The Impact of Remittances on Poverty and Human Capital: Evidence from Latin American Household Surveys. Working Paper No. 4247, Washington DC: World Bank. https://elibrary.worldbank.org/

Adams, R. H. (1991). The Economic Uses and Impact of International Remittances in Rural Egypt. Economic Development and Cultural Change, 39, 695-722. https://doi.org/10.1086/451904

Agenor, P. R. (2004). Does Globalization Hurt the Poor? International Economics and Economic Policy, 1, 21-51.

Aitken, B., Harrison, A., \& Lipsey, R. E. (1996). Wages and Foreign Ownership: A Comparative Study of Mexico, Venezuela, and the United States. Journal of International 
Economics, 40, 345-371. https://doi.org/10.1016/0022-1996(95)01410-1

Ametoglo, M. E. S., Guo, P., \& Wonyra, K. O. (2018). Regional Integration and Income Inequality in ECOWAS Zone. Journal of Economic Integration, 33, 604-628.

Anyanwu, J. C. (2011). International Remittances and Income Inequality in Africa. Working Paper Series No. 135, Tunis, Tunisia: African Development Bank.

Asadullah, M. N., Savoia, A., \& Wahiduddin, M. (2014). Paths to Development: Is There a Bangladesh Surprise? World Development, 62, 138-154.

Asamoah, M. E., Adjasi, C. K., \& Alhassan, A. L. (2016). Macroeconomic Uncertainty, Foreign Direct Investment and Institutional Quality: Evidence from Sub-Saharan Africa. Economic Systems, 40, 612-621. https://doi.org/10.1016/j.ecosys.2016.02.010

Assens, C. (2019). The Renaissance of Africa in Globalization, Management Prospective. International Journal of Organizational Sciences, 1, 141-158. https://doi.org/10.3917/riso.007.0141

Autor, D., Katz, L., \& Krueger, A. B. (1998). Computing Inequality: Have Computers Changed the Labour Market? Quarterly Journal of Economics, 113, 1169-1214. https://doi.org/10.1162/003355398555874

Bhagwati, J., \& Srinivasan, T. N. (2002). Trade and Poverty in the Poor Countries. American Economic Review, 92, 180-183. https://doi.org/10.1257/000282802320189212

Bhalla, A., \& Lapeyre, F. (1999), Poverty and Exclusion in a Global World. London: Macmillan. https://doi.org/10.1007/978-1-349-27404-8

Birdsall, N. (2002). A Stormy Day on an Open Field: A Symmetry and Convergence in the Global Economy. Paper presented at the Conference on Globalization, Living Standards and Inequality, Sydney, 27-28 May 2002, 66.

Chenery, H. (1974). Redistribution with Growth: The Economic Framework. Oxford: Oxford University Press.

Chetwynd, E., Chetwynd, F., \& Spector, B. (2003). Corruption and Poverty: A Review of Recent Literature. Washington DC: Management Systems International.

Collier, P., \& Dollar, D. (2002). Globalization, Growth, and Poverty: Building an Inclusive World Economy. Washington DC: World Bank Publications.

Collier, P., \& Gunning, J. W. (1999). Explaining African Economic Performance. Journal of Economic Literature, 37, 64-111. https://doi.org/10.1257/jel.37.1.64

Culpeper, R. (2005). Approaches to Globalization and Inequality within the International System. Overarching Concerns Program Paper No. 6, Geneva, Switzerland: United Nations Research Institute for Social Development.

Dalgaard, C. J., \& Erickso, L. (2009). Reasonable Expectations and the First Millennium Development Goal: How Much Can Aid Achieve? World Development, 37, 1170-1181. https://doi.org/10.1016/j.worlddev.2008.11.003

Davis, D. R., \& Mishra, P. (2007). Stolper-Samuelson Is Dead: And Other Crimes of Both Theory and Data. In A. Harrison (Ed.), Globalization and Poverty (pp. 87-108). Chicago, IL: University of Chicago Press. https://doi.org/10.7208/chicago/9780226318004.003.0003

Do, Q. T., \& Levchenko, A. (2009). Trade, Inequality, and the Political Economy of Institutions. Journal of Economic Theory, 144, 1489-1520.

https://doi.org/10.1016/j.jet.2008.11.007

Dollar, D., \& Kraay, A. (2003). Growth Is Good for the Poor. Economic Growth, 7, 195-225. https://doi.org/10.1023/A:1020139631000

Dollar, D., \& Kraay, A. (2004). Trade, Growth and Poverty. The Economic Journal, 114, 
22-49. https://doi.org/10.1111/j.0013-0133.2004.00186.x

Dreher, A. (2006). Does Globalization Affect Growth? Evidence from a New Index of Globalization. Applied Economics, 38, 1091-1110.

https://doi.org/10.1080/00036840500392078

Easterly, W. (2004). Channels from Globalization to Inequality: Productivity World versus Factor World. In Brookings Trade Forum (pp. 39-81). Brookings Institution Press. https://doi.org/10.1353/btf.2005.0005

Farzana, N. K. (2018). Globalization and Poverty Nexus: A Panel Data Analysis. Forman Journal of Economic Studies, 14, 143-174. https://doi.org/10.32368/FJES.20181407

Feenstra, R. C., \& Hanson, G. H. (1997). Foreign Direct Investment and Relative Wages: Evidence from Mexico's Maquiladoras. Journal of International Economics, 42, 371-393. https://doi.org/10.1016/S0022-1996(96)01475-4

Fiszbein, A., Kanbur, R., \& Yemtsov, R. (2014). Social Protection and Poverty Reduction: Global Patterns and Some Targets. World Development, 61, 167-177.

https://doi.org/10.1016/j.worlddev.2014.04.010

Fukuda-Parr, S. (2011). Theory and Policy in International Development: Human Development and Capability Approach and the Millennium Development Goals. International Studies Review, 13, 122-132. https://doi.org/10.1111/j.1468-2486.2010.01003.x

Fukuda-Parr, S., \& Hulme, D. (2011). International Norm Dynamics and the "End of Poverty”: Understanding the Millennium Development Goals. Global Governance, 17, 17-36. https://doi.org/10.1163/19426720-01701002

Goff, M., \& Singh, R. (2014). Does Trade Reduce Poverty? A View from Africa. Journal of African Trade, 1, 5-14. https://doi.org/10.1016/j.joat.2014.06.001

Goldberg, P. K., \& Pavcnik, N. (2004). Trade, Inequality, and Poverty: What Do We Know? Evidence from Recent Trade Liberalization Episodes in Developing Countries. Working Paper 10593, Cambridge, MA: National Bureau of Economic Research. https://doi.org/10.3386/w10593

Graham, C. (2004). Globalization and Poverty, Inequality, and Vulnerability: Some Insights from the Economics of Happiness. Paper presented at the UNUWIDER Project Meeting on the Impact of Globalization on the World's Poor, Helsinki, 29-30 October 2004, 33.

Gubert, T., Lassourd, T., \& Mesplé-Somps, S. (2010). Migrant Remittances, Poverty and Inequality in Mal-Revue Economique.

Gyimah-Brempong, K. (2002). Corruption, Economic Growth, and Income Inequality in Africa. Economics of Governance, 3, 183-209. https://doi.org/10.1007/s101010200045

Harrison, A., \& McMillan, M. (2007). On the Links between Globalization and Poverty. The Journal of Economic Inequality, 5, 123-134. https://doi.org/10.1007/s10888-006-9041-9

Hérault, N. (2007). Trade Liberalisation, Poverty and Inequality in South Africa: A Computable General Equilibrium-Microsimulation Analysis. Economic Record, 83, 317-328. https://doi.org/10.1111/j.1475-4932.2007.00417.x

Herzer, D., Hühne, P., \& Nunnenkamp, P. (2014). FDI and Income Inequality-Evidence from Latin American Economies. Review of Development Economics, 18, 778-793.

Hulme, D., Antonio, S., \& Kunal, S. (2015). Governance as a Global Development Goal? Setting, Measuring and Monitoring the Post-2015 Development Agenda, ESID Working Paper No. 32, Manchester: University of Manchester.

https://doi.org/10.2139/ssrn.2425238 
Kanbur, R. (1998). Income Distribution Implications of Globalization and Liberalization in Africa. Ithaca, NY: Cornell University Mimeo.

Kenny, C. (2015). End Poverty in All Its Forms Everywhere. United Nations Chronicle, 51, 4-5. https://doi.org/10.18356/0aec43e1-en

Klein, M. W., \& Olivei, G. P. (2008). Capital Account Liberalization, Financial Depth, and Economic Growth, No. 7384. NBER Working Papers from National Bureau of Economic Research, Inc. https://doi.org/10.1016/j.jimonfin.2008.05.002

Kweka, J., \& Mboya, P. (2004). Regional Integration and Poverty: The Case Study of Tanzania.

Kwon, H., \& Kim, E. (2014). Poverty Reduction and Good Governance: Examining the Rationale of the Millennium Development Goals. Development and Change, 45, 353-375. https://doi.org/10.1111/dech.12084

Mahmud, W., Asadullah, M. N., \& Savoia, A. (2013). Bangladesh's Achievements in Social Development Indicators: Explaining the Puzzle. Economic and Political Weekly, 48, 26-28.

Majeed, M. T., \& Khan, F. N. (2019). Do Information and Communication Technologies (ICTs) Contribute to Health Outcomes? An Empirical Analysis. Quality and Quantity: International Journal of Methodology, 53, 183-206. https://doi.org/10.1007/s11135-018-0741-6

McCulloch, N., Winters, L. A., \& Cirera, X. (2001). Trade Liberalization and Poverty: A Handbook. London: Centre for Economic Policy Research. https://books.google.com/

McGee, C. (2000). Childhood Experiences of Domestic Violence. London: Jessica Kingsley Publishers. https://books.google.com/

Nissanke, M., \& Thorbecke, E. (2006). Channels and Policy Debate in the Globalization-Inequality-Poverty Nexus. World Development, 34, 1338-1360. https://doi.org/10.1016/j.worlddev.2005.10.008

Nissanke, M., \& Thorbecke, E. (2008). Introduction: Globalization-Poverty Channels and Case Studies from Sub-Saharan Africa. African Development Review, 20, 1-19. https://doi.org/10.1111/j.1467-8268.2008.00174.x

North, D. (1990). Institutions, Institutional Change and Economic Performance. Cambridge, MA: Cambridge University Press. https://doi.org/10.1017/CBO9780511808678

Obstfeld, M., \& Taylor, A. M. (2001). Globalization and Capital Markets. Paper presented at the NBER conference on Globalization in Historical Perspective, Santa Barbara, 4-5 May 2001, 3.

Peemans, J. P. (1996). The Globaliste Utopia. New Books of IUED, No. 5. (Cited in Neo-Liberal Globalization to the Question of Inequality and Poverty)

Pray, C. E., Huang, J., Ma, D., \& Qiao, F. (2003). Impact of Bt Cotton in China. World Development, 29, 813-825. https://doi.org/10.1016/S0305-750X(01)00010-9

Ridzuan, A. R., Ismail, N. A., \& Che Hamat, A. F. (2017). Does Foreign Direct Investment Successfully Lead to Sustainable Development in Singapore? Economies, 5, 29.

Rodrik, D. (2007). One Economics, Many Recipes: Globalization, Institutions, and Economic Growth. Princeton, NJ: Princeton University Press. https://doi.org/10.2307/j.ctvcm4jbh

Rogoff, K. (2003). Globalization and Global Disinflation. Economic Review Federal Reserve Bank of Kansas City, 88, 45-78.

Rudra, N., \& Tobin, J. (2017). When Does Globalization Help the Poor? Annual Review of Political Science, 20, 287-307. 
Samimi, P., Lim, G. C., \& Buang, A. A. (2011). Globalization Measurement: Notes on Common Globalization Indexes. Journal of Knowledge Management, Economics and Information Technology, 1, 1-20.

Schoch, M., \& Lakner, C. (2020). The Number of Poor People Continues to Rise in Sub-Saharan Africa, Despite a Slow Decline in the Poverty Rate. UNDP.

Sindzingre, A. (2005). Explaining Threshold Effects of Globalization on Poverty: An Institutional Perspective. WIDER Research Paper No. 2005/53, Finland: United Nations University (UNU). https://doi.org/10.2139/ssrn.931559

Smith, L. C., \& Haddad, L. (2015). Reducing Child Undernutrition: Past Drivers and Priorities for the Post-MDG Era. World Development, 68, 180-204.

https://doi.org/10.1016/j.worlddev.2014.11.014

Sumner, A., \& Tiwari, M. (2009). After 2015: What Are the Ingredients of an "MDG-PLUS: Agenda for Poverty Reduction? The Journal of the Development Studies, 21, 834-843. https://doi.org/10.1002/jid.1621

Taylor, J., Mora, J., \& Adams, R. (2005). Remittances, Inequality and Poverty: Evidence from Rural Mexico. https://books.google.com/?hl=zh-CN

Tebaldi, E., \& Mohan, R. (2010). Institutions and Poverty. The Journal of Development Studies, 46, 1047-1066.

Uzonwanne, M. C. (2018). Economic Globalization and Poverty Reduction: A Nigerian Perspective, Journal of Economics and Political Economy, 114, 22-49.

Vernon, R. (1979). The Product Cycle Hypothesis in a New International Environment. Oxford Bulletin of Economics and Statistics, 41, 255-267. https://doi.org/10.1111/j.1468-0084.1979.mp41004002.x

Waage, J., Banerji, R., Campbell, O., \& Chirwa, E. (2010). The Millennium Development Goals: A Cross-Sectoral Analysis and Principles for Goal Setting after 2015. The Lancet Commissions, 376, 991-1023.

Williamson, J. G. (2005). Winners and Losers over Two Centuries of Globalization. In Wider Perspectives on Global Development. Studies in Development Economics and Policy (pp. 136-174). London: Palgrave Macmillan. https://doi.org/10.1057/9780230501850_6

World Bank (2002). Globalization, Growth and Poverty. A World Bank Research Report, New York: Oxford University Press for the World Bank. https://doi.org/10.1596/0-8213-5048-X

World Bank (2016). World Development Indicators. Washington DC: World Bank. 